\title{
Antidepressant Activity of Some Fractions of the Basil Leaves (Ocimum basilicum L.) on the Swiss Webster Male Mice
}

\author{
(Aktivitas Antidepresi Beberapa Fraksi Daun Selasih \\ (Ocimum basilicum L.) pada Mencit Jantan \\ Galur Swiss Webster)
}

MUHARAM PRIATNA ${ }^{1}$, YEDY PURWANDI SUKMAWAN ${ }^{1}$, HENDY SUHENDY $^{2 *}$

'Department of Pharmacology and Clinical Pharmacy, Program Study of Pharmacy, Institute of Health Science Bakti Tunas Husada, Tasikmalaya - 46115, West Java, Indonesia.

${ }^{2}$ Department of Pharmacognosy, Program Study of Pharmacy, Institute of Health Science Bakti Tunas Husada, Tasikmalaya - 46115, West Java, Indonesia.

Submitted 8 March 2018, Accepted 28 September 2018

\begin{abstract}
The objective of the study is to determine the antidepressant activity of some fractions of the leaves of Ocimum basilicum L. The experimental methods are using Force Swimming Test and Tail Suspension Test. The experiment was divided into seven groups. Negative control group (CMC $1 \%$ ), Positive control group (fluoxetine $0.052 \mathrm{mg} / 20 \mathrm{~g} \mathrm{BW}$ of mice), test I group (fraction of $n$-hexane $50 \mathrm{mg} / \mathrm{Kg} \mathrm{BW}$ ), test II group (fraction of ethyl acetate $50 \mathrm{mg} / \mathrm{Kg} \mathrm{BW}$ ), test III group (fraction of ethanol $50 \mathrm{mg} / \mathrm{Kg} \mathrm{BW}$ ), test IV group (combination of cyproheptadine $0.0208 \mathrm{mg} / 20 \mathrm{~g} \mathrm{BW}$ of mice and Fluoxetine $0,052 \mathrm{mg} / 20 \mathrm{~g} \mathrm{BW}$ of mice) and test $\mathrm{V}$ group (combination of cyproheptadine 0,0208 $\mathrm{mg} / 20 \mathrm{~g} \mathrm{BW}$ of mice and fraction of ethyl acetate $50 \mathrm{mg} / \mathrm{Kg} \mathrm{BW}$ ). The ethyl acetate fraction showed significant difference $(\mathrm{p}<0.05)$ than negative control group and it had better time reduction than other groups. Serotonin receptors role may involve since cyproheptadine administration increase immobility time of the test $\mathrm{V}$ group. Ethyl acetate fraction showed the best antidepressant activity with possibility of serotonin receptors site action.
\end{abstract}

Keywords: Antidepressant, basil, leaves, force swimming test, tail suspension test.

\begin{abstract}
Abstrak: Menentukan aktivitas antidepresi beberapa fraksi daun Ocimum basilicum L. Metode percobaan menggunakan Force Swimming Test dan Tail Suspension Test. Percobaan dibagi kedalam tujuh kelompok. Kelompok kontrol negatif (CMC 1\%), kelompok kontrol positif (fluoxetine 0,052 $\mathrm{mg} / 20 \mathrm{~g} \mathrm{BB}$ mencit), kelompok uji I (fraksi $n$-heksana $50 \mathrm{mg} / \mathrm{Kg} \mathrm{BB}$ ), kelompok uji II (fraksi etil asetat $50 \mathrm{mg} / \mathrm{Kg} \mathrm{BB}$ ), kelompok uji III (fraksi etanol $50 \mathrm{mg} / \mathrm{Kg} \mathrm{BB}$ ), kelompok uji IV (kombinasi siproheptadin $0,0208 \mathrm{mg} / 20 \mathrm{~g}$ BB mencit dan fluoxetine $0,052 \mathrm{mg} / 20 \mathrm{~g}$ BB mencit) dan kelompok uji $\mathrm{V}$ (kombinasi siproheptadin $0,0208 \mathrm{mg} / 20 \mathrm{~g} \mathrm{BB}$ mencit dan fraksi etil asetat $50 \mathrm{mg} / \mathrm{Kg}$ BB). Fraksi etil asetat menunjukkan perbedaan bermakna $(\mathrm{p}<0,005)$ dibandingkan dengan kelompok kontrol negatif dan memiliki waktu penurunan immobilitas yang paling baik dibandingkan kelompok yang lain. Aktivitas kerja kemungkinan direseptor serotonin karena pemberian siproheptadin meningkatkan waktu immobilitas pada kelompok uji V. Fraksi etil asetat memberikan aktivitas antidepresi paling baik dengan kemungkinan lokasi kerja pada reseptor serotonin.
\end{abstract}

Keywords: Antidepresi, selasih, daun, force swimming test, tail suspension test.

*Correspondence Author: Hp : 082214398037

Email: radhwan04@gmail.com 


\section{INTRODUCTION}

PEOPLE sometimes experience painful state physically, mentally or socially. Illness caused by mental experience increase year to year due to the clashes in family life, society and economy. At present, the problems faced more difficult and the pressure is getting great ${ }^{(1)}$. People who can't deal with this condition will develop into diseases such as hypertension, stroke, asthma, sleeplessness, fatigue, anxiety, depression, amenorrhea, and others ${ }^{(2)}$. One of the mental illness discussed in this study is depression. Depression is a heterogeneous state accompanied by some typical and repetitive bodily reaction ${ }^{(3)}$. The prevalence of depression in Indonesia is quite high around $6 \%$, while in the world about $5-10 \%$ per year $^{(4)}$.

Selective Serotonin Reuptake Inhibitor (SSRI), Tricyclic Antidepressant (TCA), Serotonin Norephiperine Reuptake Inhibitor, Monoamine Oxidase Inhibitor (MAO-I), and Serotonin Dopamine Activity Modulator (SDAMs) are effective medications for depression. However, failure of the medications arises, caused not by clinical resistance but by medication noncompliance. This noncompliance related to tolerability and safety of the medication ${ }^{(5,6)}$.

Tolerability, fast action and high remission are ideal drugs for depression. Herbal medicine is known to have good tolerability and safety, with the general belief that "Natural is Better" (7,8). Ocimum basilicum L. is one of medicinal plant known to have an antidepressant effect ${ }^{(9,10)}$. Many researches have been conducted about this activity, but the activity of some fractions of this plants is unknown. Therefore, we are conducting an assay of antidepressant activity of some fractions of the leaves of basil (Ocimum basilicum L.) against male swiss webster mice and determine the antidepressant mechanism possibility

\section{MATERIALS AND METHODS}

MATERIALS. Plant Material. Fresh leaves of Ocimum basilicum L. were collected from Manoko Bandung, Indonesia. Plant identification and authentication were done by the Herbarium of School of Life Sciences, Institut Teknologi Bandung, Indonesia.

Animals. Swiss webster strain of male mice weighing between 20-30 g were used and purchased from The Institute of Health Science Bakti Tunas Husada Tasikmalaya, West Java, Indonesia. The mice were housed in wire mesh cages under standard conditions (temperature, $25-30^{\circ} \mathrm{C}, 12 \mathrm{~h}$ lights and 12 $\mathrm{h}$ dark cycles) and allowed to acclimatize for 5 days. The mice were fed with standard pellets diet and water was given ad libitum. The animals treatment have been in accordance with the guide for the care and use of laboratory animals. All efforts were conduct to minimize animal suffering.

METHODS. Preparation of Extract. The leaves were washed in tap water and shade-dried after which they were reduced to a fine powder by grinding. Extraction of the grinded Ocimum basilicum L. leaves as much as 90 grams is soaked using $96 \%$ ethanol solvent and stored in a place protected from sunlight while being shaken. The maceration was carried out in triplicate. The results of maceration are filtered and concentrated using a rotary evaporator. The extract is referred to as concentrated ethanolic extract. Then the process of fractionation use liquid-liquid extractions from concentrated ethanolic extracts is based on the difference of polarity of the organic solvent in. Ethanol concentrated extract was dissolved in a water-ethanol solvent (6:4) then fractionated with $n$-hexane solvent in a $1: 1(\mathrm{v} / \mathrm{v})$ ratio. The fractionation is done by separating funnel, so that two fractions of $n$-hexane fraction with ethanol-water fraction are obtained. The fractinations was continued between the ethanol-water fraction with the ethyl acetate fraction with a ratio of $1: 1$. Three fractions were obtained which are ethanolwater fraction, $n$-hexane fraction and ethyl acetate fraction. Moreover, each fraction is then concentrated using a rotary evaporator. Concentrated fraction then used as an fraction test for antidepressants activity.

Phytochemical Screening. Phytochemical screening is performed on simplicia and each fraction of ethanol-water, $n$-hexane and ethyl acetate to determine secondary metabolite content such as alkaloids, flavonoids, tannins, phenols, saponins, quinones, steroids/triterpenoids and monoterpene/ sesquiterpen.

Forced Swimming Test. The experimental group was divided into 7 groups they are negative control group (CMC 1\%), positive control group (fluoxetine $0.4 \mathrm{mg} / \mathrm{Kg} \mathrm{BW}$ ), test I group (fraction of $n$-hexane 50 $\mathrm{mg} / \mathrm{Kg} \mathrm{BW}$ ), test II group (fraction of ethyl acetate $50 \mathrm{mg} / \mathrm{Kg} \mathrm{BW}$ ), test III group (fraction of ethanol $50 \mathrm{mg} / \mathrm{Kg} \mathrm{BW}$ ), Test IV group (cyproheptadine $0,0208 \mathrm{mg} / 20 \mathrm{~g} \mathrm{BW}$, followed by fluoxetine 0,052 $\mathrm{mg} / 20 \mathrm{~g} \mathrm{BW}, 30$ minutes apart) and Test V group (cyproheptadine $0,0208 \mathrm{mg} / 20 \mathrm{~g} \mathrm{BW}$, followed by ethyl acetate fraction $50 \mathrm{mg} / \mathrm{Kg} \mathrm{BW}$ ). The test performed after one hour at the last treatment for 6 minutes and counting after 2 minutes ${ }^{(7)}$.

Tail Suspension Test. The test performed after one hour at the last treatment for 6 minutes and counting after 2 minutes. The animals are suspended by their tails with tape, in such position that it cannot escape or hold on to neraby surfaces ${ }^{(7)}$. 
Statistical Analysis. The results are presented in the mean \pm SE. Statistical analysis using ANOVA and followed with LSD (Least Significant Difference) using SPSS 16.0.

\section{RESULT AND DISCUSSION}

RESULT. Preliminary Phytochemical Screening. Phytochemical screening is performed on simplicia and fractions to determine the presence of secondary metabolites such as alkaloids, flavonoids, tannins, phenols, quinones, saponins, steroids/triterpenoids, monoterpenes and sesquiterpenes.

Phytochemical screening of simplicia, $n$-hexane fraction and ethyl acetate fraction shown in the Table 1. The simplicia are contained flavonoids, steroids/ triterpenoids and monoterpenes/sesquiterpen. The ethanol fraction showed the presence of flavonoids and saponins, while for $n$-hexane and ethyl acetate fraction positive for flavonoid, steroid/triterpenoid and monoterpene/sesquiterpene.

Forced Swimming Test. The ethyl acetate fraction showed significant difference $(p<0.05)$ than negative control group. Although the fraction of $n$-hexane and ethanol fraction did not give significant difference ( $p>0.05$ ), but they are able to decrease of immobility time at $20.1 \%$ and $24.7 \%$ respectively. Positive group (Fluoxetine) able to decrease the immobility time at $35.9 \%$.

Administration add-on of Cyproheptadine decrease the effect of fluoxetine as indicated by an increase in immobility time at $42.7 \%$ than Fluoxetine alone. This results showed cyproheptadine able to block fluoxetine effectivity.

The test group of ethyl acetate fraction that previously given Cyproheptadine also gave the same pattern as in the Fluoxetine group. The ethyl acetate fraction activity was eliminated by the Cyproheptadine.
Tail Suspension Test. The test results of antidepressant activity with Tail Suspension Test method showed similar result with Forced Swimming Test method that showed that ethyl acetate fraction gave significant difference $(p<0.05)$ in decreasing of immobility time compared with negative control group and gave decreasing of immobility time better than the positive group, $n$-hexane fraction and ethanol fraction. Hexane fraction group and the positive group in the Tail Suspension Test method gave significant differences $(p<0.05)$ in decreasing immobility time compared to the negative control group. While in the ethanol fraction group did not give a significant difference $(p>0.05)$ compared to the negative control group, although when viewed by a numerous group of ethanol fraction gives time immobility decrease when compared with the negative control group equal to $7.9 \%$.

In testing of cyproheptadine activity against fluoxetine with Tail Suspension Test method gives the same result as for Forced Swimming Test method where ethyl acetate fraction group previously given cyproheptadine gives an increase of immobility time compared with only giving ethyl acetate fraction alone of $33.3 \%$ Which originally gave significant difference $(p<0.05)$ to the negative group to no significant difference $(\mathrm{p}>0.05)$.

Similarly, testing of the ethyl acetate fraction group was given cyproheptadine previously using the Tail Suspension Test method showed similar results as the Forced Swimming Test method. The ethyl acetate group previously gave cyproheptadine resulted in an increase in immobility time compared to the ethyl acetate group without cyproheptadine.

DISCUSSION. Testing of antidepressant activity against some fractions of the Ocimum basilicum plant that is n-hexane fraction, ethyl acetate fraction and ethanol fractions derived from the fractionation of the viscous extract from the ethanol extract is an

Table 1. Results of phytochemical screening.

\begin{tabular}{|c|c|c|c|c|c|}
\hline No & $\begin{array}{l}\text { Secondary } \\
\text { metabolite }\end{array}$ & Simplisia & $\begin{array}{l}\text { Hexane } \\
\text { fraction }\end{array}$ & $\begin{array}{c}\text { Ethyl acetate } \\
\text { fraction }\end{array}$ & Ethanol fraction \\
\hline 1 & Alkaloids & - & - & - & - \\
\hline 2 & Flavonoids & + & + & + & + \\
\hline 3 & Tannins & - & - & - & - \\
\hline 4 & Phenols & - & - & - & - \\
\hline 5 & Saponins & - & - & - & + \\
\hline 6 & Quinones & - & - & - & - \\
\hline 7 & $\begin{array}{c}\text { Steroids/ } \\
\text { Triterpenoids }\end{array}$ & + & + & + & - \\
\hline 8 & Monoterpene/ sesquiterpenes & + & + & + & - \\
\hline
\end{tabular}


Table 2. Result of antidepressant activity test by force swimming test method.

\begin{tabular}{clc}
\hline No & \multicolumn{1}{c}{ Group } & Mean of immobility (s) \\
\hline 1 & Negative control group (CMC 1\%) & $131.4 \pm 69.4$ \\
2 & Positive control group (Fluoxetine $0.052 / 20 \mathrm{~g} \mathrm{BW}$ mice) & $84.2 \pm 59.4$ \\
3 & Test I group/ n-hexane fraction $(50 \mathrm{mg} / \mathrm{Kg} \mathrm{BW})$ & $105.0 \pm 23.6$ \\
4 & Test II group/ ethyl acetate fraction $(50 \mathrm{mg} / \mathrm{Kg} \mathrm{BW})$ & $37.0 \pm 43.2^{*}$ \\
5 & Test III group/ ethanol fraction $(50 \mathrm{mg} / \mathrm{Kg} \mathrm{BW})$ & $99.0 \pm 60.0$ \\
\hline
\end{tabular}

Exp: Tests were performed with 5 replications, ${ }^{*}=$ showing significant differences when compared with negative groups.

Table 3. Results of cyproheptadine and fluoxetine combination against fluoxetine alone by force swimming test method.

\begin{tabular}{clc}
\hline No & \multicolumn{1}{c}{ Group } & Mean of immobility (s) \\
\hline 1 & Negative control group (CMC 1\%) & $131 \pm 69.4$ \\
2 & $\begin{array}{l}\text { Positive control group (Fluoxetine 0.052/20 g BW mice) } \\
3\end{array}$ & $\begin{array}{l}\text { Test IV group (combination of cyproheptadine 0,0208 mg/20 g BW of mice and } \\
\text { fluoxetine 0,052 mg/20 g BW of mice) }\end{array}$ \\
\hline
\end{tabular}

Exp: Tests were performed with 5 replications, $*=$ showing significant differences when compared with negative groups.

Table 4. Results of cyproheptadine and ethyl acetate fraction combination against ethyl acetate alone by force swimming test method.

\begin{tabular}{clc}
\hline No & \multicolumn{1}{c}{ Group } & Mean of immobility (s) \\
\hline 1 & Negative control group (CMC 1\%) & $131 \pm 69,4$ \\
2 & $\begin{array}{l}\text { Test II group/ ethyl acetate fraction }(50 \mathrm{mg} / \mathrm{Kg} \mathrm{BW}) \\
3\end{array}$ & $\begin{array}{l}\text { Test V group (combination of cyproheptadine } 0,0208 \mathrm{mg} / 20 \mathrm{~g} \mathrm{BW} \text { of mice and } \\
\text { fraction of ethyl acetate 50 mg/Kg BW) }\end{array}$ \\
\hline
\end{tabular}

Exp: Tests were performed with 5 replications, $*=$ showing significant differences when compared with negative groups.

Table 5. Results of antidepressant activity testing by tail suspension test method.

\begin{tabular}{clc}
\hline No & \multicolumn{1}{c}{ Group } & $\begin{array}{c}\text { Mean of immobility } \\
\text { (s) }\end{array}$ \\
\hline 1 & Negative control group (CMC 1\%) & $216 \pm 35.7$ \\
2 & Positive control group (Fluoxetine 0.052/20 g BW mice) & $107.6 \pm 57.6^{*}$ \\
3 & Test I group/ n-hexane fraction (50mg/Kg BW) & $138.6 \pm 24.4^{*}$ \\
4 & Test II group/ ethyl acetate fraction (50mg/Kg BW) & $120.6 \pm 42.4^{*}$ \\
5 & Test III group/ ethanol fraction (50mg/Kg BW) & $198.8 \pm 67.9$ \\
\hline
\end{tabular}

Exp: Tests were performed with 5 replications, $*$ = showing significant differences when compared with negative groups.

Table 6. Results of cyproheptadine and fluoxetine combination against fluoxetine alone by tail suspension test method.

\begin{tabular}{|c|c|c|}
\hline No & Group & Mean of immobility (s) \\
\hline 1 & Negative control group (CMC 1\%) & $216.0 \pm 35.7$ \\
\hline 2 & Positive control group (Fluoxetine $0.052 / 20 \mathrm{~g} \mathrm{BW}$ mice) & $107.6 \pm 57.6^{*}$ \\
\hline 3 & $\begin{array}{l}\text { Cyproheptadine group }(0.0208 \mathrm{mg} / 20 \mathrm{~g} \mathrm{BW} \text { mice) }+ \text { Positive control group (Fluoxetine } \\
0.052 / 20 \mathrm{~g} \mathrm{BW} \text { mice) }\end{array}$ & $161.4 \pm 46.4$ \\
\hline
\end{tabular}

Exp: Tests were performed with 5 replications, ${ }^{*}=$ showing significant differences when compared with negative groups. 
Table 7. Results of cyproheptadine and ethyl acetate

fraction combination against ethyl acetate alone by tail suspension test method.

\begin{tabular}{llc}
\hline No & \multicolumn{1}{c}{ Group } & Mean of immobility (s) \\
\hline 1 & Negative control group (CMC 1\%) & $216,0 \pm 35,7$ \\
2 & Test II group (50mg/Kg BW) & $120,6 \pm 42,4^{*}$ \\
3 & Cyproheptadine group $(0,0208 \mathrm{mg} / 20 \mathrm{~g}$ BW mice $)+$ Test II group $(50 \mathrm{mg} / \mathrm{Kg} \mathrm{BW})$ & $181,7 \pm 91,7$ \\
\hline
\end{tabular}

Exp: Tests were performed with 5 replications, $*=$ showing significant differences when compared with negative groups.

effort to develop and search for new antidepressant drugs derived from natural materials. The search and development of this new antidepressant drug use a simple method of behavioral testing that is Forced Swimming Test and Tail Suspension Test as a first step before performing a complex test.

Forced Swimming Test and Tail Suspension Test are a method that has a good prediction validity, fast and economical to detect a substance that has activity as an antidepressant. In addition, both methods are also based on the same principle of determining the duration of immobility when test animals are exposed to an inescapable situation ${ }^{(11,12)}$.

The results of antidepressant activity testing using the two methods above showed that ethyl acetate fraction group $(50 \mathrm{mg} / \mathrm{Kg} \mathrm{BW})$ gave the best and consistent result in decreasing immobility time when compared with the negative group, positive group, $n$-hexane fraction and ethanol fraction. Based on these results, the ethyl acetate fraction is continued to further testing intended to determine the general description of its mechanism by providing prior cyproheptadine to the ethyl acetate fraction group. Cyproheptadine is intended to determine the anti-serotonin effect of fluoxetine. Cyproheptadine is an anti-serotonin and antihistamine drug that has been shown to inhibit the effects of serotonin ${ }^{(13,14,15)}$.

Cyproheptadine administration using Forced Swimming Test method can decrease the effect of fluoxetine as indicated by the increase of immobility time compared with $42.7 \%$ of the fluoxetine alone. In addition, testing of cyproheptadine activity against fluoxetine by Tail Suspension Test method gave the same result as the Forced Swimming Test method where ethyl acetate fraction group previously gave cyproheptadine resulted in an increase in immobility time compared to only the fraction of ethyl acetate alone for $33.3 \%$. This indicates that the effect of serotonin through increased serotonin concentrations produced by fluoxetine through resistance to the retrieval of serotonin neurotransmitters may be inhibited by cyproheptadine as an antiserotonergic by inhibiting serotonin to interact with its receptors ${ }^{(14,16,17)}$.
The ethyl acetate fraction which given cyproheptadine previously gives the same pattern as in fluoxetine group. The significant decrease of immobility time $(p<0.05)$ can be eliminated in the presence of cyproheptadine. In addition, ethyl acetate fraction group testing using Tail Suspension Test method showed the same result as Forced Swimming Test method. The ethyl acetate group previously gave cyproheptadine resulted in an increase of immobility time compared with ethyl acetate group without cyproheptadine of $33.62 \%$. This provides a consistent result and as a confirmation that the ethyl acetate group in its activity decreases the time of immobility through the presence of the role of serotonin neurotransmitter, since cyproheptadine is known to inhibit serotonin receptors $^{(16,17)}$.

However, further research is needed on the compound responsible for the immobility reduction activity, although flavonoids and terpenoids or essential oils are considered compounds that provide antidepressant activity, especially when involving interference with monoamine ${ }^{(18,19,20)}$. The ethyl acetate fraction proved to have a positive flavonoid and essential oil content (terpenoid) based on phytochemical screening results performed on the ethyl acetate fraction. According to ${ }^{(21)}$, Ocimum basilicum contains flavonoids such as luteo.6-arabinose.8-glucose, luteo.6-glucose.8arabinose, apig.6-rhaminose.8-galactose, apig.6rhaminose.8-glucose, apig.6-glucose.8-rhaminose, routine, hespiridin, rosmarinic acid, apig.7-oneohespiroside, apiginine-7-glucose, quercitin, naringenin, hespirtin, campferol, apigenin. Naringenin has antidepressant activity through the serotonergic and noradrenergic system ${ }^{(18)}$. While linalool and 1.8 cineol are essential oils that are considered to have an effect as antidepressants and mood improvements ${ }^{(15,22)}$.

\section{CONCLUSION}

The three fractions of $n$-hexane, ethyl acetate and ethanol showed that ethyl acetate fraction give the best result, consistent and give significant difference $(\mathrm{p}<$ 
$0.05)$ in decreasing time immobility with the mechanism of action may through the role of serotonin. However, more study are needed to find compound that give antidepressant activity from the ethyl acetate fraction.

\section{ACKNOWLEDGMENT}

Authors thanks to Dr. Ruswanto as a chief of research, development and community service of Institute of Health Science Bakti Tunas Husada for the support.

\section{REFERENCES}

1. Priatna M, Kalpataru Y, Sukmawan YP. Uji efektifitas antidepresi infusa daun selasih (Ocimum basilicum Linn.) terhadap mencit jantan galur swiss webster. Tasikmalaya: STIKes BTH; 2010.

2. Corwin JE. Patofisiologi. Jakarta: EGC; 2001.

3. Ganiswara. Farmakologi dan terapi. Jakarta: UIP; 2005.

4. Ministry Department of Health. Riset kesehatan dasar. Research and Health Development Agency Ministry Department of Health of Republic Indonesia; 2013.

5. Jerry LH, Ravinder NB, Pascale MB, Louise BA, Rachel CL. 2016. Depression medication. [online] diambil dari http://emedicine.medscape.com/article/286759medication. diakses 17 Juli 2017.

6. Sweetman SC. Martindale the complete drug reference. $30^{\text {th }}$ ed. London: Pharmaceutical Press; 2009.

7. Zheng M, Li Y, Shi D, Liu C, Zhao J. Antidepressan-like effect of flavonoid extracted from Apocynum veneteum leaves in mice: the involvement of monoaminergic system in mice. Afr. J.Pharm. Pharmacol. 2014; 8(29): 765-74.

8. Sukandar E Y, Ridwan A, Sukmawan Y P. Vasodilatation effect of ethanolic extract of Anredera cordifolia, Sonchus arvensis L., and ursolic acid on isolated rabbit aortic and frog heart. Int J Pharm Pharm Sci. 2016; 8(2):145-9.

9. Tewari D, Pandhey HK, Sah AN, Meena H, Chander $\mathrm{V}$, Singh R et al. Phytochemical, antioxidant and antidepressant evaluation of Ocimum basilicum, $O$. tenuiflorum, O. kilimandscharicum Grown in India. TBAP 2015; 5(2):120-31.

10. Apsera L. Efek minyak atsiri daun kemangi Ocimum basilicum sebagai antidepresan pada tikus wistar: ditinjau dari immobility time dengan metode force swim test. Surabaya: Undip; 2010.

11. Castagne V, Moser P, Roux, Porsolt RD. Rodent models of depression: forced UNIT 8.10A swim and tail suspension behavioral despair tests in rats and mice. Current Protocols in Neuroscience 8. 2011; 10A:1-8.

12. Santosh P, Venugopl R, Nilakash AS, Kunjbihari S, Mangala L. Antidepressant activity of methanolic extract of passiflora foetida leaves in mice. Int J Pharm Pharm Sci. 2011; 3(1):112-5.

13. Stone CA, Wenger HC, Ludden CT, Stavorski JM, Ross CA. Antiserotonin-antihistaminic properties of cyproheptadine. Journal of Pharmacology and Experimental Therapeutics January. 1961; 131(1):7384.

14. Lappin R and Auchincloss EL. Treatment of the serotonin syndrome with cyproheptadine. N Engl J Med. 1994; 331:1021-22.

15. Rossi S. Australian medicines handbook. Adelaide: The Australian Medicines Handbook Unit Trust; 2013.

16. Martin P, Waters N, Schimdt CJ, Carlsson A, Carlson ML. "Rodent data and general hypothesis : antipsychotic action exterd through 5-HT2A receptor antagonism is dependent in increased serotonergic tone". Journal of Neural Transmission. 1998; 105(45):365-96.

17. Lindley $\mathrm{C}$ and Blower, P. Oral serotonin type 3-receptor antagonists for prevention of chemotherapy-induced emesis. American Journal of Health-System Pharmacy. 2000; 57 (18):1685-97.

18. Yi LT, Li CF, Zhan X, Cui CC, Xiao F, Zhou LP, et al. Involvement of monoaminergic system in antidepressant-like effect of flavonoids naringenin in mice. Prog Neuropsychopharmacol Biol Psychiatry. 2010; 34:1223-28.

19. Fernandez et al. Central nervous system depressant action of flavonoid glycosides. European Journal of Pharmacology. 2006; 539:168-76.

20. Rabwani M, Sajjadi S E, Vaezi A. Evaluation of anxiolytic and sedative effect of essential oil and hydroalcoholic extract of Ocimum basilicum L. and chemical composition of its essential oil. Res Pharm Sci 2015; 10(6): 535-43.

21. Hozayen WG, El-Desouky MA, Soliman HA, Ahmed RR, Khaliefa AK. Antiosteoporotic effect of Petroselinum crispum, Ocimum basilicum and Cichorium intybus L. in glucocorticoid-induced osteoporosis in rats. BMC Complementary and Alternative Medicine. 2016; 16:165.

22. Moss M and Oliver L. Plasma 1,8-cineole correlates with cognitive performance following exposure to rosemary essential oil aroma. Ther Adv Psychopharmacol. 2012; 2(3):103-13. 